\title{
DEVELOPMENT OF NEW MATERIALS FOR WORK AND BACKUP ROLLS IN PLATE MILLS*
}

Andreas Cestonaro ${ }^{1}$ Peter Heisterkamp ${ }^{2}$

\begin{abstract}
Roll grade evolution in plate mill applications is traditionally following the development in hot strip mills. New grades normally find their way into service only after being successfully implemented in hot strip production. The majority of the plate mills worldwide are using work roll grades that have been invented before the 1980's. But today the demands in the mills are pushed by sophisticated product mixes and longer rolling campaigns. The result of this development is a higher wear rate on the work rolls and as a consequence roll hardness is increased and advanced roll materials are used. The backup rolls are also affected by this. The wear rate is higher and the mechanical impact in terms of contact pressure and work hardening is increasing. This paper outlines the results of the roll grade development at Gontermann-Peipers and introduces new materials for work and backup rolls for plate mills.
\end{abstract}

Keywords: Work roll; Backup roll; Plate mill; Roll grade development; HSS rolls

Dipl.-Ing., Quality Manager, Gontermann-Peipers GmbH, Siegen, Germany.

Dipl.-Ing., R\&D Manager, Gontermann-Peipers GmbH, Siegen, Germany.

* Technical contribution to the 51st Rolling Seminar - Processes, Rolled and Coated Products, October $28^{\text {th }}$ to $31^{\text {st }}, 2014$, Foz do lguaçu, PR, Brazil. 


\section{INTRODUCTION}

A new generation of powerful plate mills has been developed in the recent years. These mills with rolling forces up to $120 \mathrm{MN}$ and motor power of $24 \mathrm{MW}$ are used to produce steel plates that meet the increasing demand of exceptional material properties. High rolling forces, a sophisticated product mix and a high share of thermo-mechanical and controlled rolling are challenging the capabilities of existing roll grades. In addition the mills tend to increase the service time of the rolls in order to reduce downtimes. In this environment the mills are seeking rolls with improved properties.

Gontermann-Peipers (GP) has a longtime experience and is manufacturing work and backup rolls since the year 1825.12 .000 rolls have been delivered only in the last 15 years, almost 4.000 backup rolls and more than 8000 work rolls. The majority of these rolls have been manufactured for hot and cold strip mills. For Heavy Plate Mills GP has delivered 200 backup rolls and 850 work rolls to customers all over the world. Recently GP is testing new grades of work and backup rolls that have been developed to meet the challenges in modern plate mills.

\section{DEMANDS ON ROLLS IN PLATE MILL}

The rolling conditions in modern plate mills are very much depending on the product mix and final dimensions and thus on the applied rolling strategies as illustrated in figure 1.

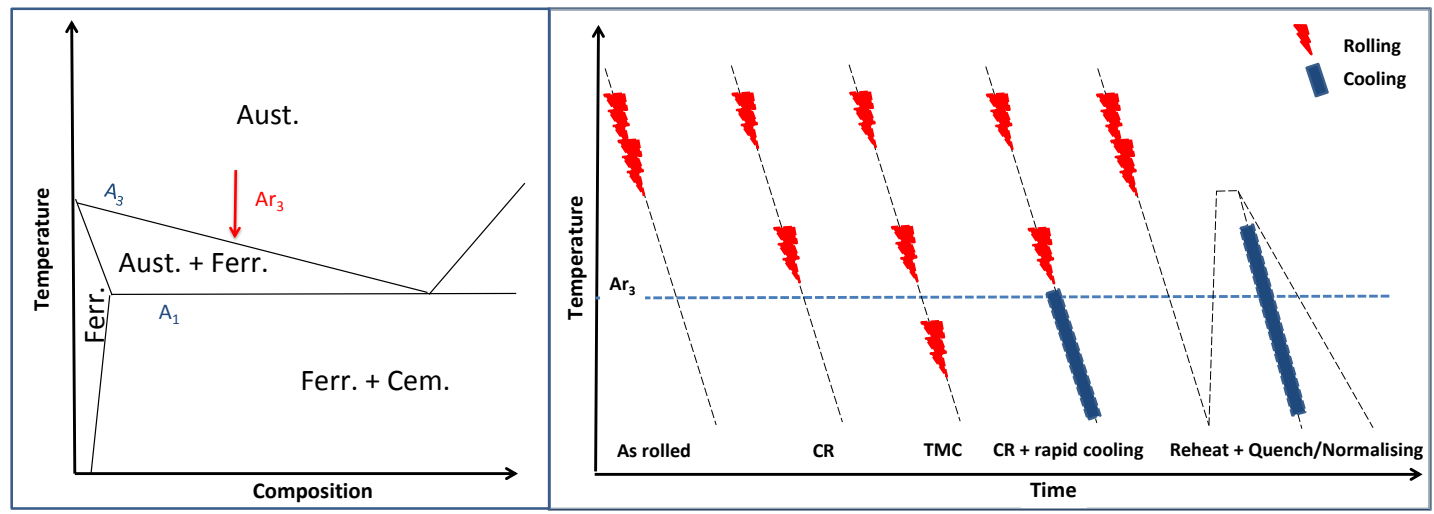

Figure 1: Rolling strategies [1]

The impact on the rolls is dramatic. The excessive rolling loads induce high Hertzian stresses on the roll in combination with an increased wear due to low temperatures at the final passes. Figure 2 illustrates the impact of the share of TM- plates rolled in one campaign on the work roll performance. The mills also tend to increase the rolling campaigns in order to reduce downtimes and improve productivity. This is also affecting the load on the rolls, since the wear profiles are deeper and the load is only carried on the parts of the roll barrel that are outside the wear profiles. The combination of high wear and high stresses is challenging the fatigue limits of conventional roll materials.

* Technical contribution to the 51st Rolling Seminar - Processes, Rolled and Coated Products, October $28^{\text {th }}$ to $31^{\text {st }}, 2014$, Foz do Iguaçu, PR, Brazil. 

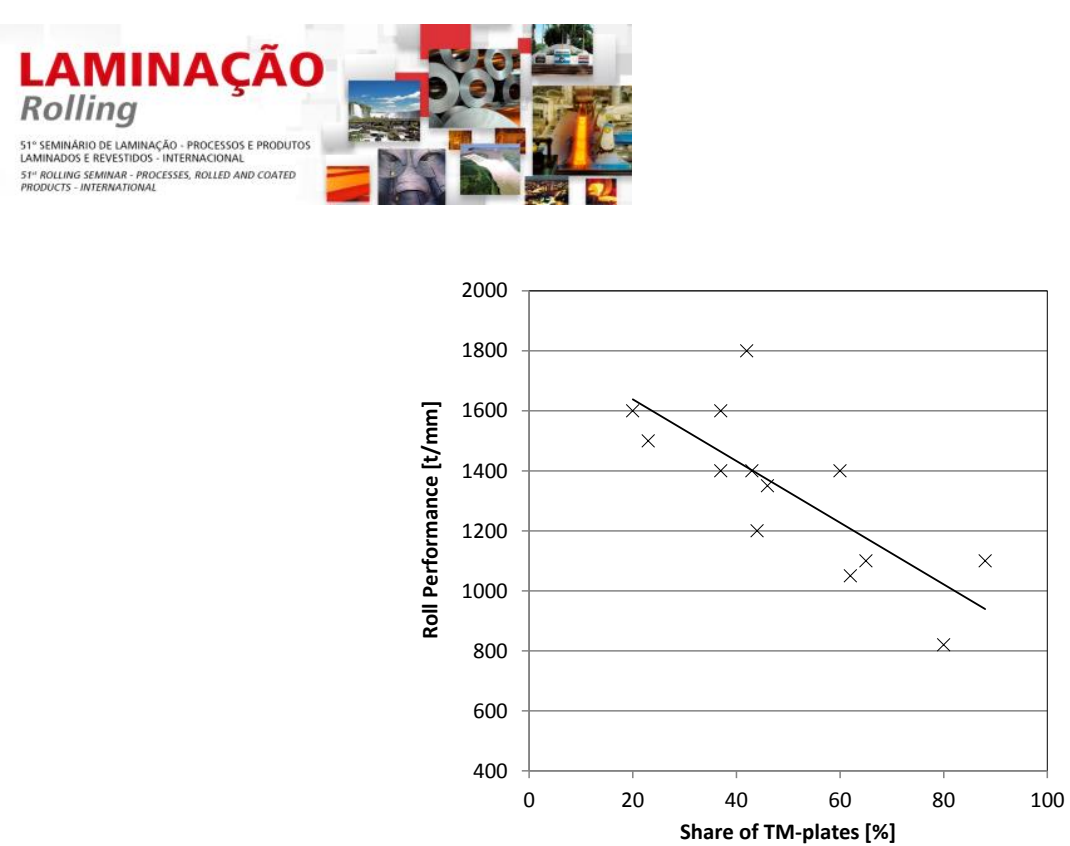

Figure 2: Work roll performance for Thermo-Mechanical (TM) rolling [2]

The new generation of powerful driving spindles has also caused problems. A series of neck breakages in the area of the driving spade prove that the fatigue strength of the conventional neck materials is insufficient (Figure 3).

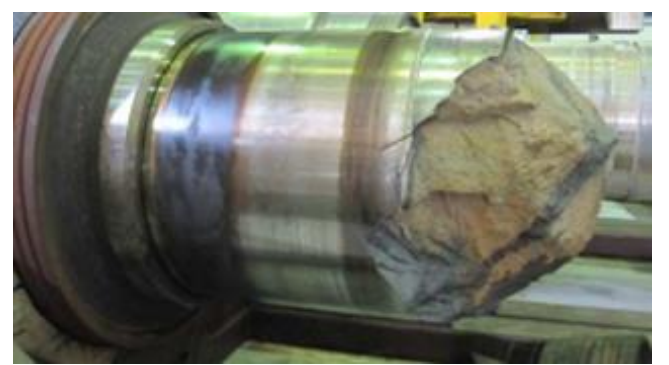

Figure 3: Neck failure due to drive end torque.

In order to meet the challenges of modern plate mills the mills are seeking rolls with a better wear resistance in combination with improved mechanical properties, in particular a high fatigue strength.

\section{WORK ROLLS IN PLATE MILLS}

For the work rolls the main requirements are:

- Good wear resistance to allow long rolling campaigns, reduced mill downtimes and excellent dimensional profiles of the finished products.

- High fatigue strength, in particular for compression, to withstand high rolling loads and to allow longer campaigns.

- High resistance to fire-crack formation.

- Low oxidation tendency to obtain an excellent product surface.

- High reliability to allow a stable rolling process without unscheduled roll changes due to roll induced problems.

- Excellent grip conditions to allow high deformation grades without roll slippage and to reduce the number of passes in the roughing phase (Figure 3).

- High tensile strength of neck material to withstand the high torque on modern driving spindles.

* Technical contribution to the 51st Rolling Seminar - Processes, Rolled and Coated Products, October $28^{\text {th }}$ to $31^{\text {st }}, 2014$, Foz do Iguaçu, PR, Brazil. 


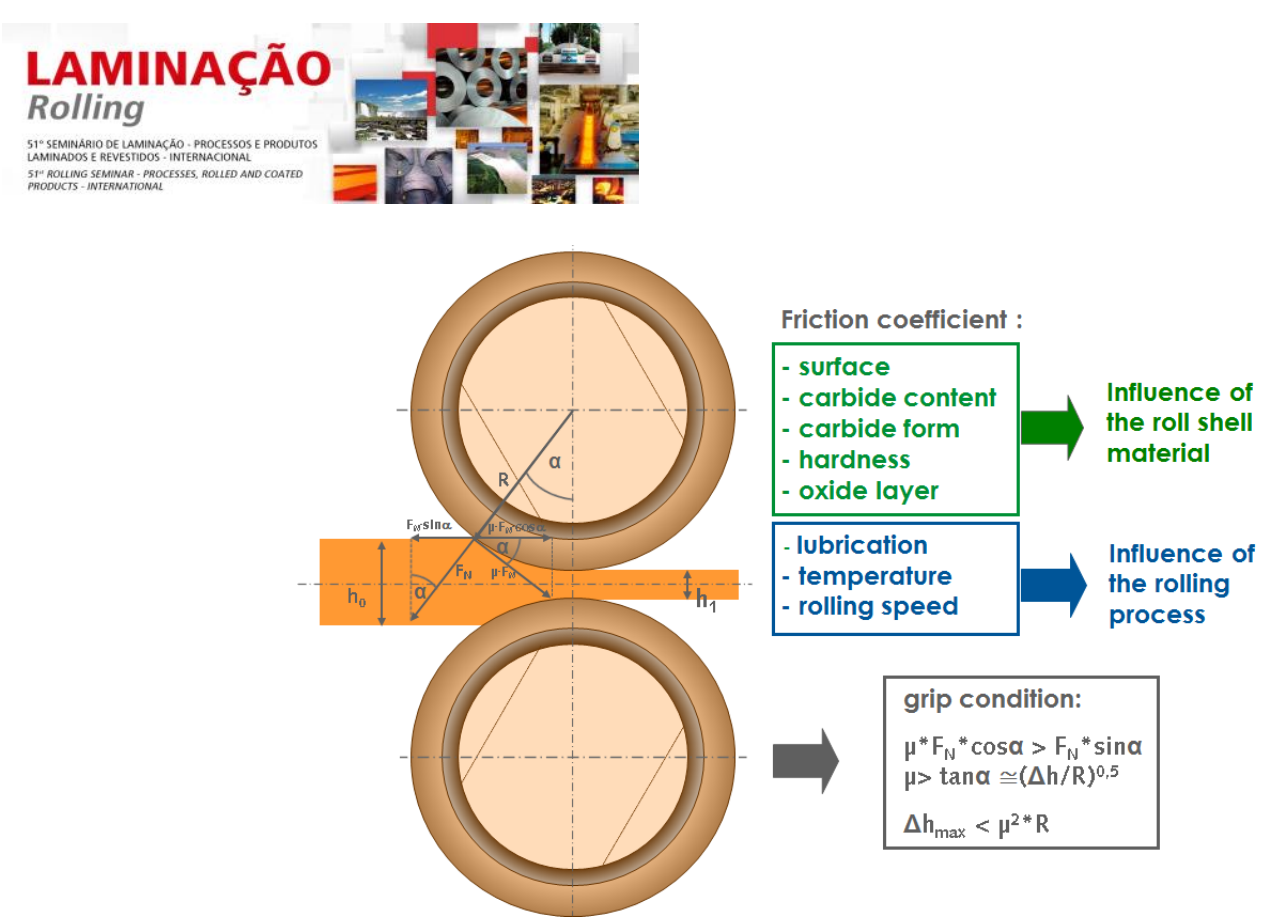

Figure 4: Influence on roll grip.

The following table 1 gives an overview of grades used in the plate mill work roll application. The most common grade is still the conventional ICDP roll showing reasonable properties with respect to wear and operational safety. The carbide enhanced (CE) ICDP grade with additional carbide building elements to improve the wear resistance was successfully implemented in the last finishing stands of hot strip mills more than 15 years ago. The performance could be increased up to $40 \%$. In plate mill applications the performance growth could not be repeated at the same level, but the hardness drop towards scrap diameter and operational safety due to optimized graphite morphology could be improved.

In Europe $80 \%$ of the plate mills use high chromium grades as standard today. In the rest of the world 90\% of all mills use ICDP. In the 1990'ies European mills increased the share of TMC rolling dramatically and thus the rolling incidents and number of damaged rolls was growing. By introducing chromium grades, which had been at that time successfully introduced in hot strip mills, the sensitivity of fire cracks and mechanical roll damage could be improved, thus decreasing the number of scrapped rolls. Parallel to this the overall roll performance was almost doubled and service length could be extended. HCS has proven to be an excellent choice for reversing roughing stands in hot strip mills for many years. This grade is not much implemented in plate mill applications but is a good alternative in roughing stands for plate mills with two stands due to good thermal properties and in particular the excellent bite angle capacity.

* Technical contribution to the 51st Rolling Seminar - Processes, Rolled and Coated Products, October $28^{\text {th }}$ to $31^{\text {st }}$, 2014, Foz do Iguaçu, PR, Brazil. 


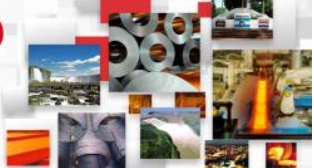

high deformation grades are more than compensated with better wear and fire crack resistance. HSS rolls have already proved in some mills to have a great potential for success in plate mills.

Table 2: Material properties

\begin{tabular}{|l|c|c|c|c|c|}
\hline & ICDP & CE-ICDP & HCI & HCS & HSS \\
\hline Operational safety & +++ & ++ & +++ & +++ & ++ \\
\hline Surface quality & ++ & + & ++ & ++ & +++ \\
\hline Bite angle capacity & ++ & ++ & + & +++ & ++ \\
\hline Sticking behavior & +++ & +++ & + & + & ++ \\
\hline Fire crack resistance & + & + & ++ & +++ & +++ \\
\hline Wear resistance & 0 & + & ++ & ++ & +++ \\
\hline
\end{tabular}

\subsection{GP Development of Plate Mill Work Rolls}

\subsubsection{HSS rolls}

The main objective of this development is to improve the wear resistance significantly, in order to allow longer campaigns and to reduce the mill downtimes. Positive side effects should be improved product surfaces, better dimensional profiles and reduced grinding operations in the roll shop. Numerous developments have been made in the last years to improve the hardness and wear resistance of work rolls.

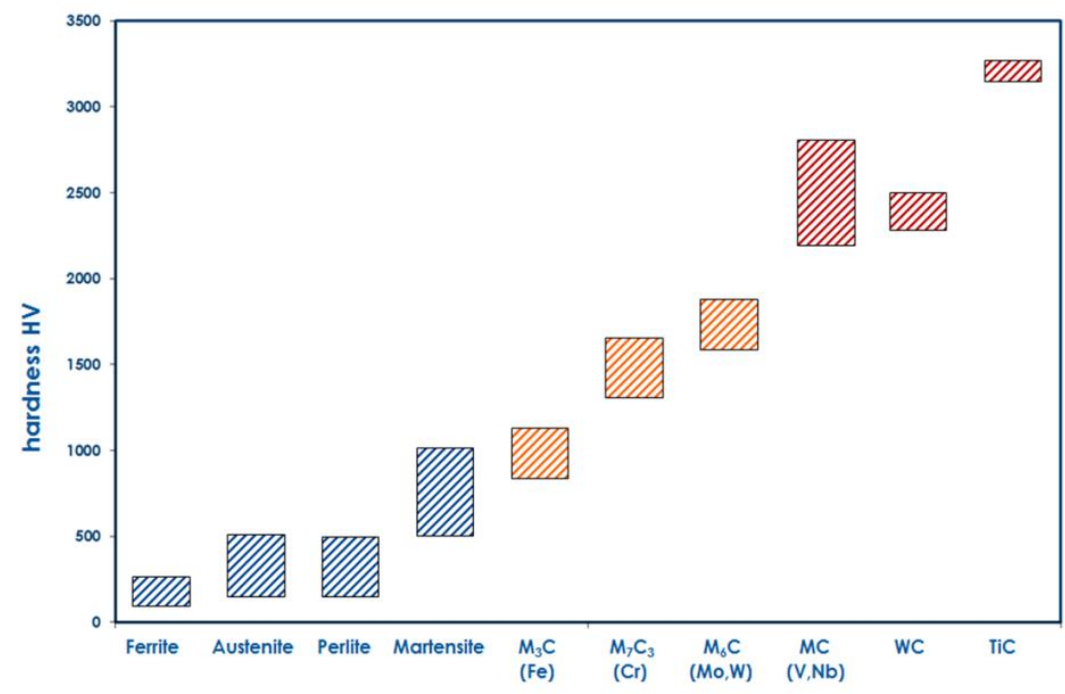

Figure 5: Hardness of different microstructure components

For many years the hardness was achieved by microstructures with a martensitic matrix and $\mathrm{M}_{3} \mathrm{C}$ and $\mathrm{M}_{7} \mathrm{C}_{3}$ carbides containing $\mathrm{Fe}, \mathrm{Cr}$ and Mo. Sometimes even $\mathrm{M}_{2} \mathrm{C}$ carbides containing $\mathrm{W}$. Today these carbides are replaced by $\mathrm{MC}$ carbides containing vanadium, niobium and titanium to increase the hardness and the wear resistance of work rolls shell materials (Figure 5). The tensile strength and hardness values of GP HPM work roll grades are illustrated in Figure 6. The main advantage of the HSS rolls are improved mechanical properties and a higher hardness. This opens the possibility for longer campaigns and higher loads which will have severe consequences on both work and backup rolls.

* Technical contribution to the 51st Rolling Seminar - Processes, Rolled and Coated Products, October $28^{\text {th }}$ to $31^{\text {st }}, 2014$, Foz do Iguaçu, PR, Brazil. 


\section{LAMINAÇÃO}

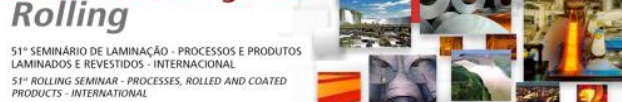

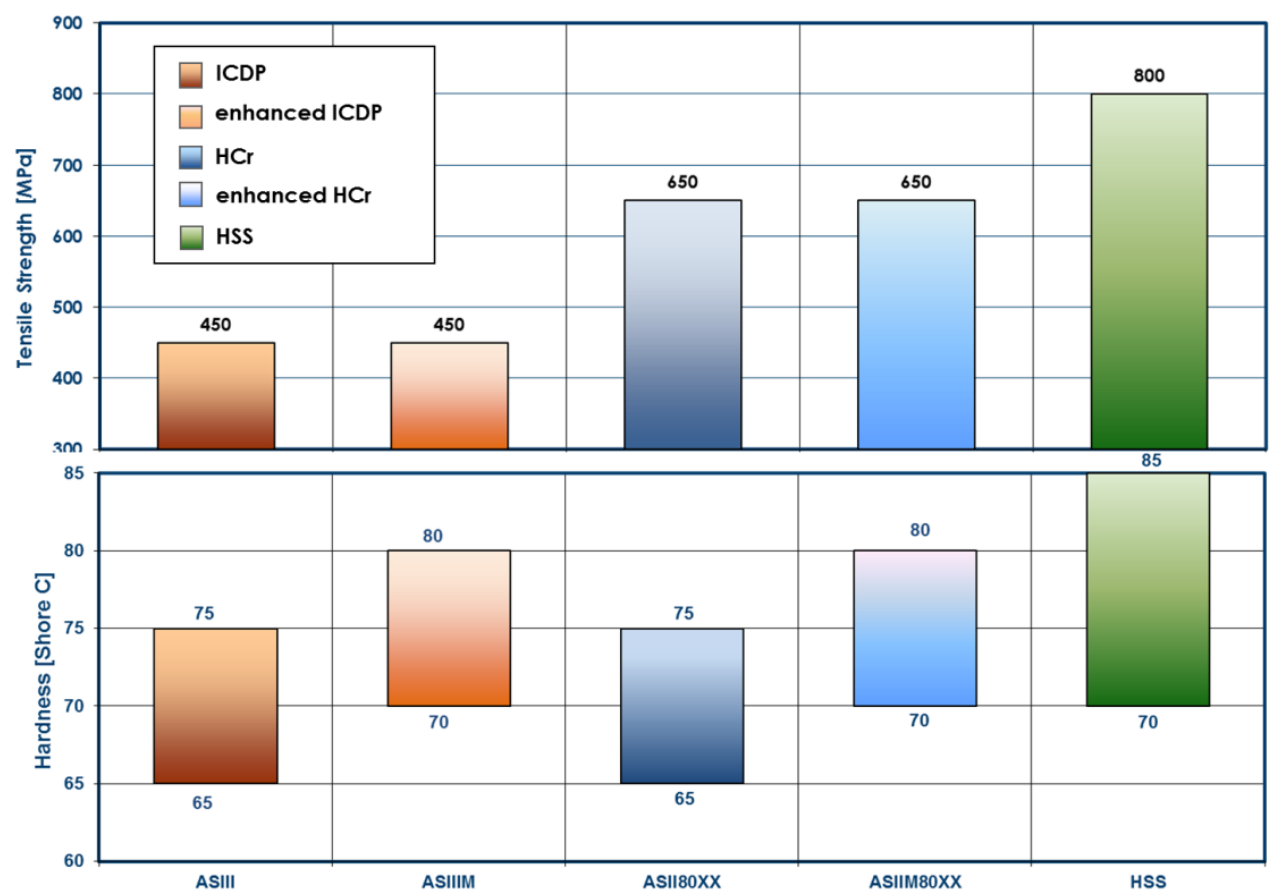

Figure 6: Hardness and tensile strength of work roll qualities for Plate Mills

Until today GP has manufactured HSS rolls for 4 different plate mills. First trials show very promising results. The operational factors like safety, surface quality and bite angle capacity are on very good levels. At the same time the wear is only marginal compared to standard grades, thus bearing a big potential for saving costs. Figure 7 illustrates a comparison of chromium rolls with HSS rolls in the roughing stand of a heavy plate mill. The average campaign length is increased by $25 \%$. At the same time the performance $\mathrm{t} / \mathrm{mm}$ is increase by $75 \%$. In single campaigns the HSS rolls were already used for 3 weeks instead of 1 week for the chromium rolls.

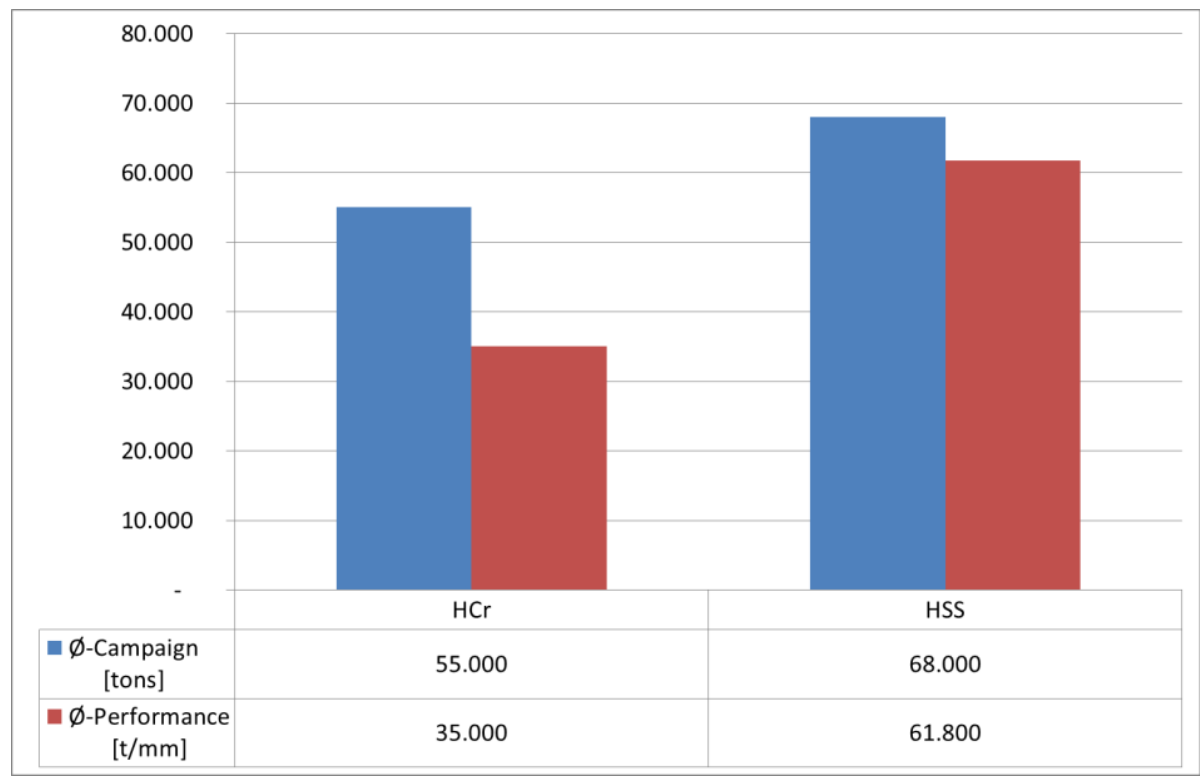

Figure 7: Comparison of different Roll grades

\subsubsection{Improved compression strength for ICDP and CE-enhanced ICDP}

The main objective of this development was to improve the resistance to compressive stresses that are caused by the high rolling loads of modern plate mills.

* Technical contribution to the 51st Rolling Seminar - Processes, Rolled and Coated Products, October $28^{\text {th }}$ to $31^{\text {st }}, 2014$, Foz do lguaçu, PR, Brazil. 


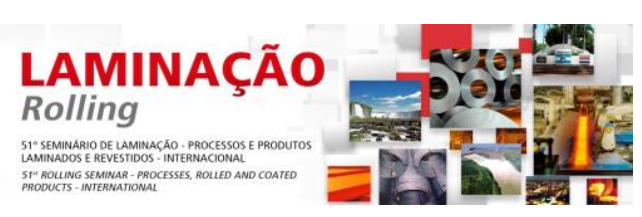

The alternating stresses can lead to subsurface fatigue cracks that can result in excessive spallings of the roll barrel.

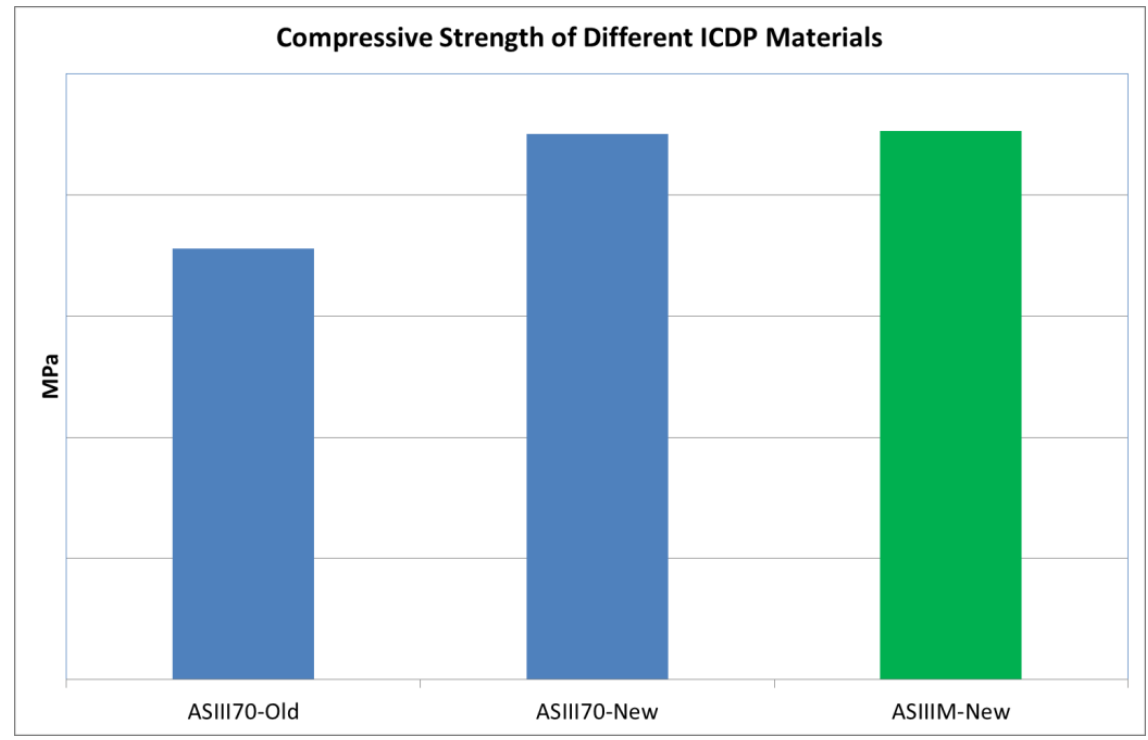

Figure 8: Compressive Strength

The compressive strength could be improved by $30 \%$ for the conventional ICDP and the carbide enhanced grade ASIIIM (Figure 8). This improvement will reduce the risk of fatigue spalling and can help to prolong the campaign length of the rolls.

\subsubsection{Improved neck material properties}

In the recent past some of the modern powerful plate mills have experienced problems with neck breakages in the area of the driving spade. These failures could be easily identified as spontaneous overload fractures due to torsional stress. More than that, mill builders are developing high performance drive spindles that will further push the performance of the new generation of hot mills. The objective of this project was to develop a drive-neck material that can withstand the high torque in modern plate mills and that will meet the demands of the mill builders.

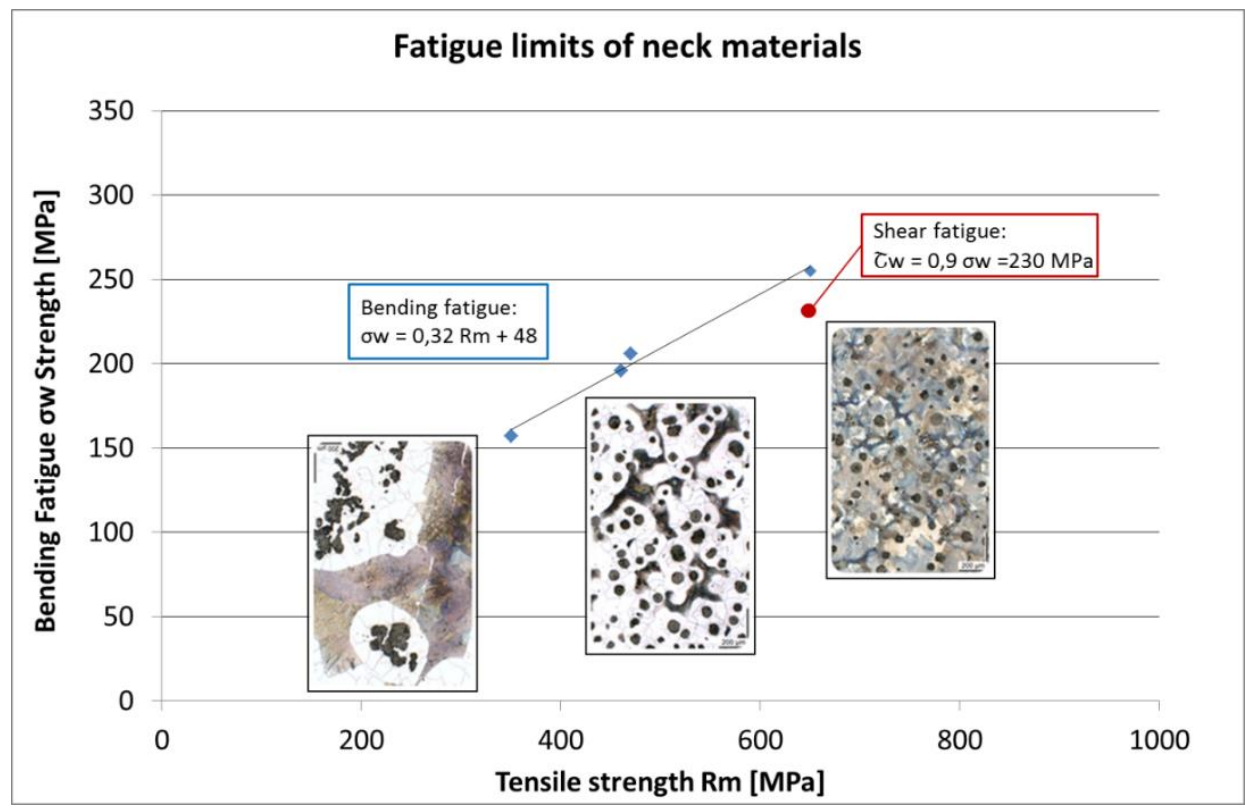

Figure 9: Neck material properties

* Technical contribution to the 51st Rolling Seminar - Processes, Rolled and Coated Products, October $28^{\text {th }}$ to $31^{\text {st }}, 2014$, Foz do Iguaçu, PR, Brazil. 
Figure 9 shows the results of the neck material improvement. The tensile strength could be increased from levels around $400 \mathrm{MPa}$ to $650-680 \mathrm{MPa}$. The bending fatigue strength was increased from $155 \mathrm{MPa}$ to $255 \mathrm{MPa}$. The linear interdependence between tensile strength and bending fatigue was confirmed. The shear fatigue value was calculated with $230 \mathrm{MPa}$.

\section{BACKUP ROLLS IN PLATE MILLS [3]}

For the backup rolls the main requirements are:

- Reliability on operation

- High rigidity

- High wear resistance

- Low hardness drop during life of roll

- $\quad$ Constant hardness on barrel surface

\subsection{GP Development of Plate Mill Backup Rolls}

Gontermann-Peipers offers two backup roll grades for plate mills:

Table 3: Chemical composition of GP HPM backup roll grades

\begin{tabular}{|c|c|c|c|c|c|c|c|}
\hline \multicolumn{1}{|c|}{ GP quality } & $\mathrm{C}$ & $\mathrm{Si}$ & $\mathrm{Mn}$ & $\mathrm{Cr}$ & $\mathrm{Mo}$ & $\mathrm{Ni}$ & $\mathrm{V}$ \\
\hline AST60 (DPS) & $0,6-0,9$ & $0,4-0,8$ & $0,5-2,0$ & $1,5-2,0$ & $0,1-0,4$ & $0,1-0,6$ & \\
\hline AST60X (DPS) & $0,3-0,8$ & $0,3-0,8$ & $0,5-2,2$ & $2,5-5,5$ & $0,6-3,0$ & $0,1-0,6$ & $0,2-1,2$ \\
\hline
\end{tabular}

The low alloyed and double poured standard grade AST60 with hardness between 40 and 52 Shore C was significantly improved in the year 2010. The chemical composition was modified, the material purity was improved and the heat treatment was optimized to obtain a fine pearlitic microstructure. The second quality is the AST60X with higher contents of $\mathrm{Cr}$ and Mo. The hardness is between 55 and 65 Shore $\mathrm{C}$ obtained with a tempered bainitic microstructure. The product was launched in May 2013.

\subsubsection{Microstructure and mechanical properties}

The microstructures of the backup roll shell materials are shown in the following picture. The fine peariltic microstructure of the low alloyed backup roll grade AST60 is shown in comparison to the fine tempered bainitic structure of the high Cr Mo alloyed grade AST60X.

* Technical contribution to the 51st Rolling Seminar - Processes, Rolled and Coated Products, October $28^{\text {th }}$ to $31^{\text {st }}$, 2014, Foz do Iguaçu, PR, Brazil. 

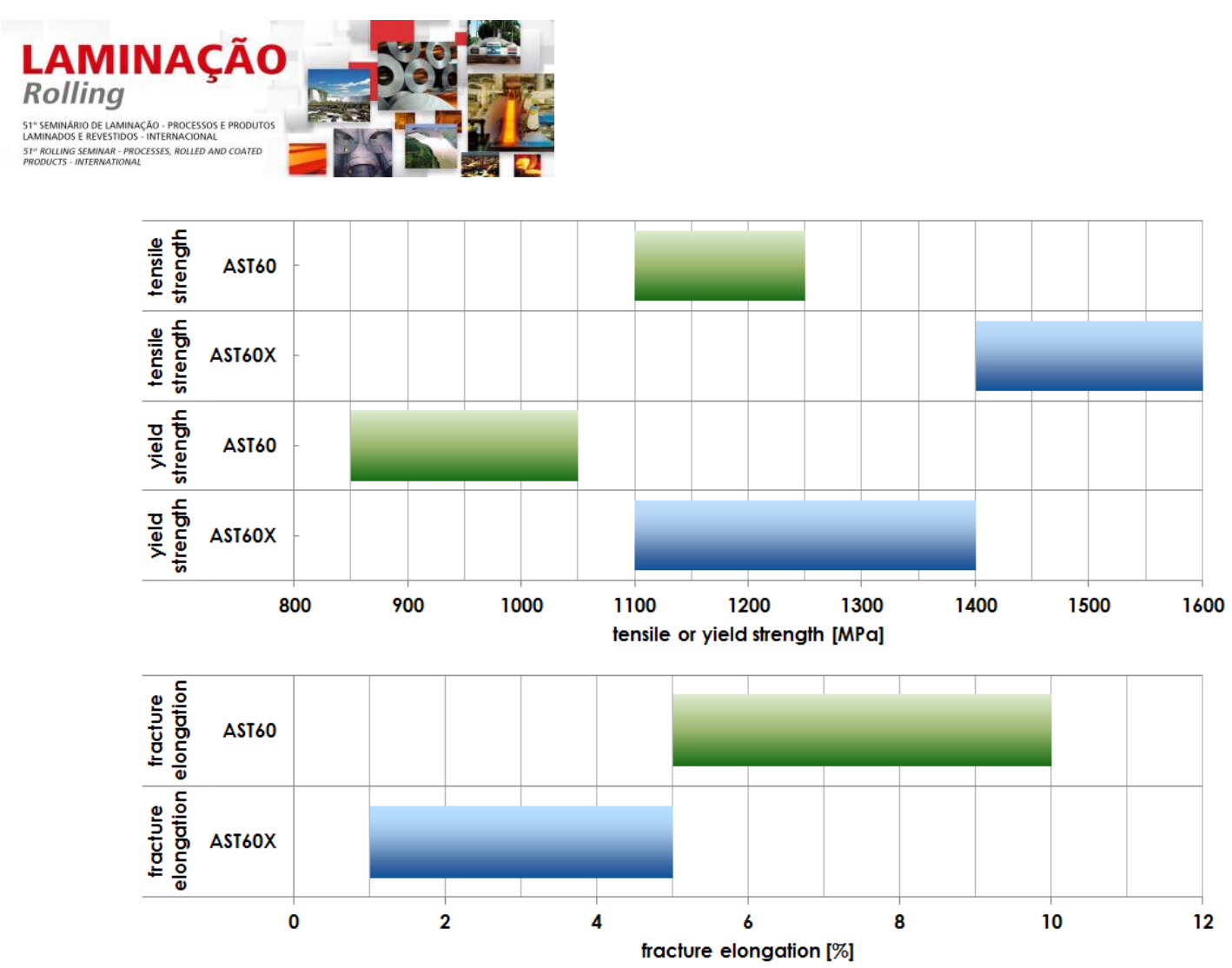

Figure 12: Mechanical properties of HPM backup roll shell material

In accordance to the tensile strength the fatigue strength of AST60X with values between 420 and $450 \mathrm{MPa}$ is on a higher level than the values of AST60 with 320 up to $360 \mathrm{MPa}$ (Figure 13).

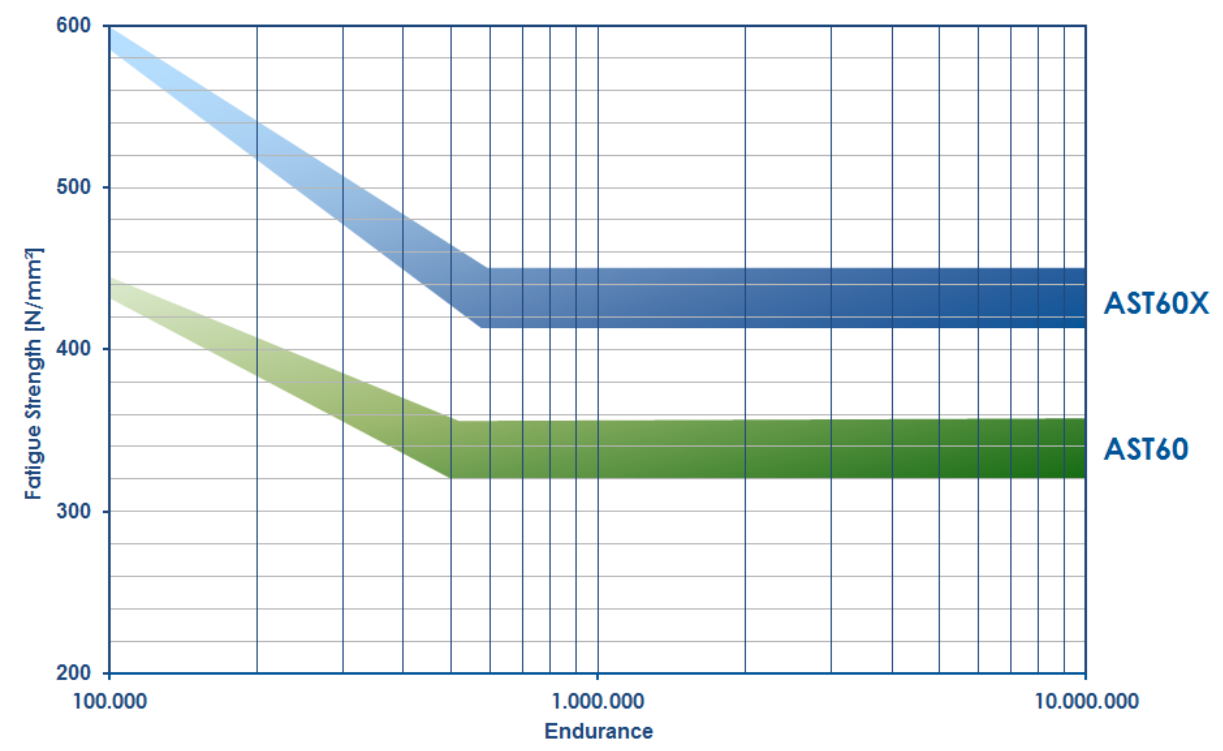

Figure 13: Fatigue strength of HPM backup roll shell material

GP designed a special device for measuring the wear resistance of roll materials together with the University of Aachen [4]. This setup allows the comparison of different roll materials by variation of cooling medium, number of revolutions and load forces.

* Technical contribution to the 51st Rolling Seminar - Processes, Rolled and Coated Products, October $28^{\text {th }}$ to $31^{\text {st }}, 2014$, Foz do Iguaçu, PR, Brazil. 

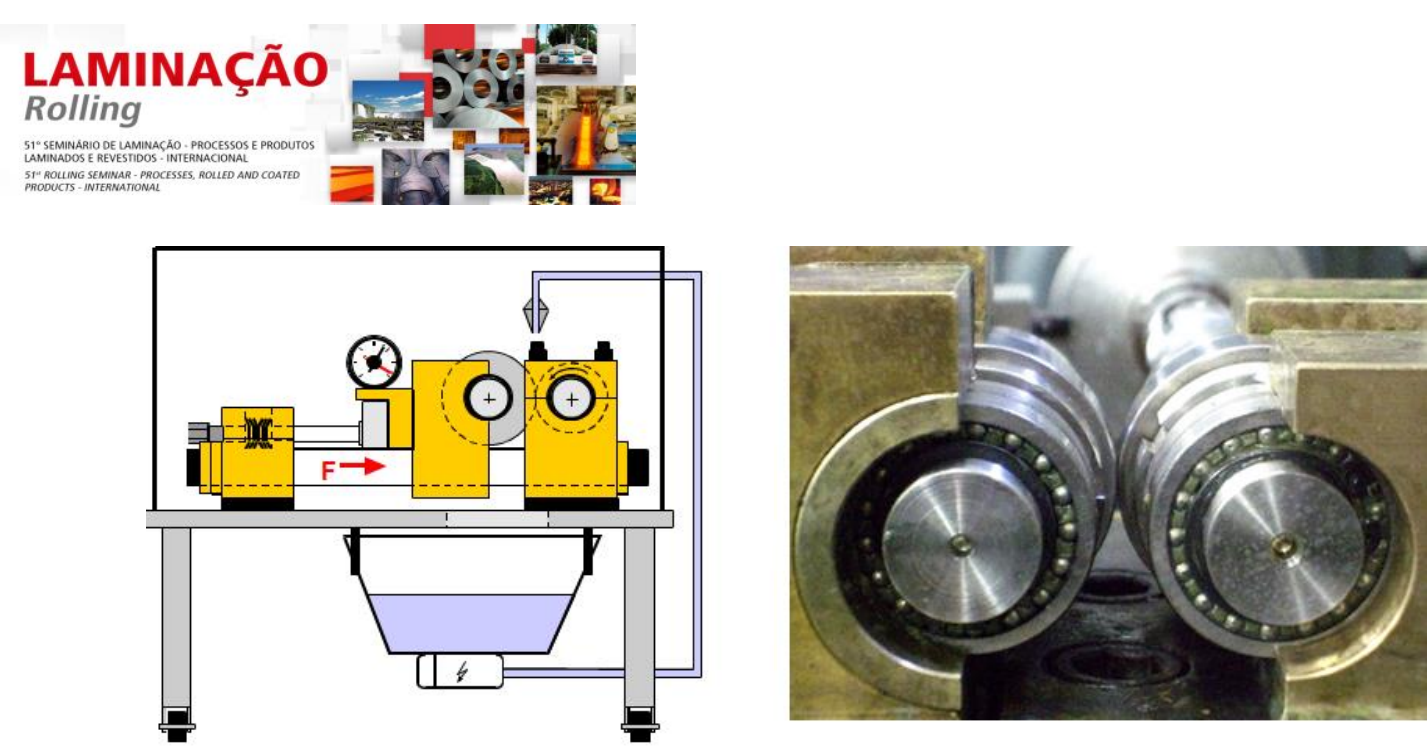

Figure 14: Wear abrasion test device

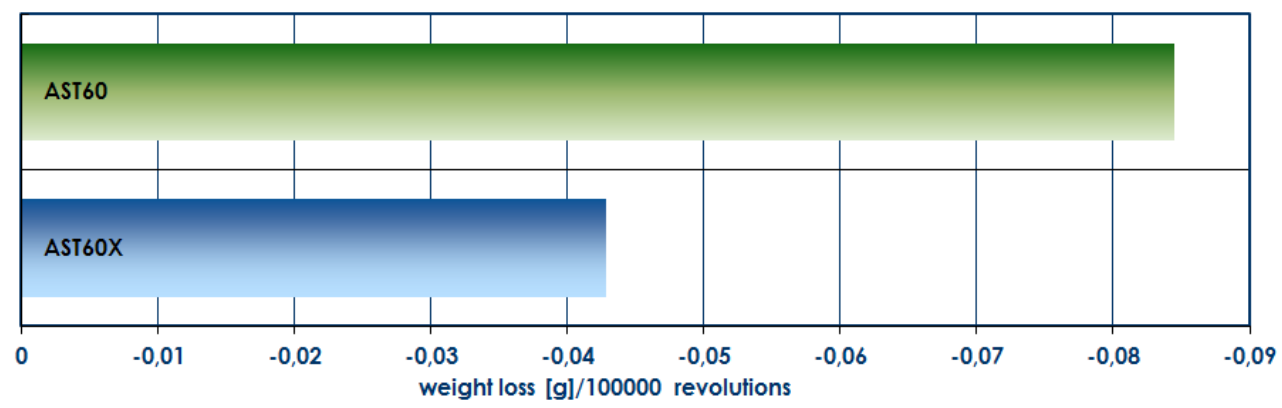

Figure 15: Wear abrasion test results

The evaluation of the results revealed a much lower wear of AST60X compared to AST60 (Figure 15).

\subsubsection{Heat Treatment}

The heat treatment of AST60 is very important for homogeneous backup roll properties. Figure 16 shows a part of the shell material TTT-diagram.

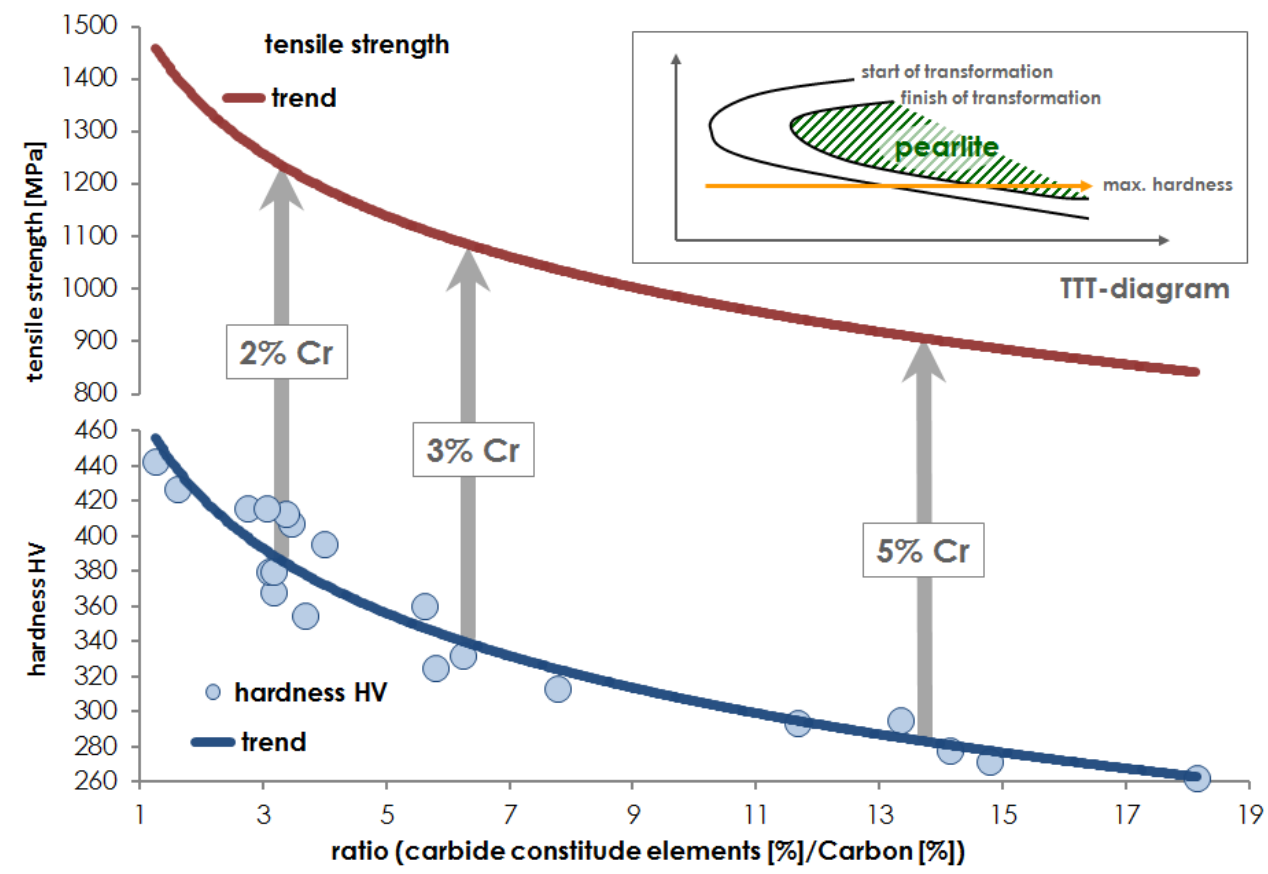

Figure 16: Maximum hardness of pearlitic microstructure

* Technical contribution to the 51st Rolling Seminar - Processes, Rolled and Coated Products, October $28^{\text {th }}$ to $31^{\text {st }}, 2014$, Foz do Iguaçu, PR, Brazil. 


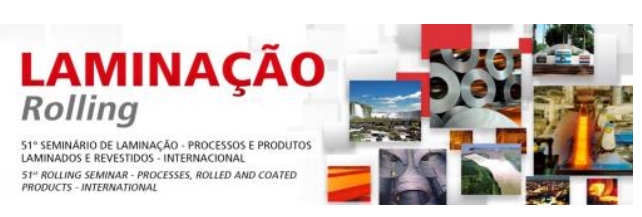

applications together with ICDP or high chromium iron work rolls GP favors the low alloyed backup roll AST60 with pearlite microstructure and a hardness between 40 and 52 Shore $\mathrm{C}$.

But in future the standard work roll grades will be more and more substituted by higher alloyed work roll grades, especially HSS rolls. In consequence the loads and the rolled tons per campaign will increase and higher mechanical properties will be needed. For this higher loaded application GP recommends the higher $\mathrm{Cr}$ Mo alloyed backup roll with hardness between 55 and 65 Shore $C$. Because of the higher crack sensitivity of this grade sophisticated roll maintenance will be necessary (Figure 20).

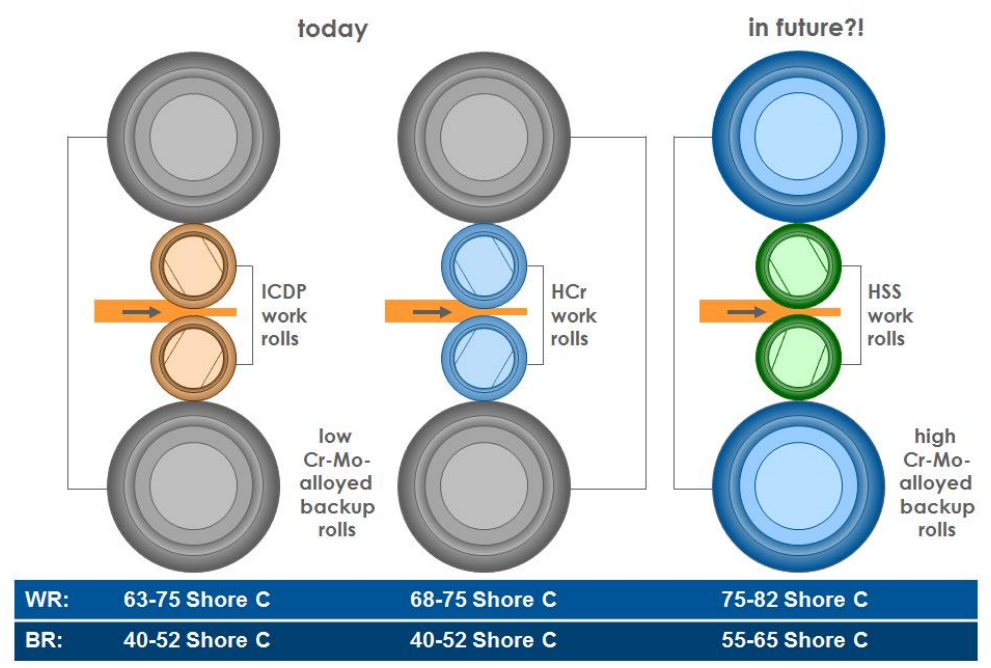

Figure 20: Work and backup roll grade combinations

The most important properties of both backup roll grades in comparison are summarized in the following table. The AST60X should only be ordered in case of higher loads and longer campaigns. For standard applications the AST60 is the right grade to be used.

Table 4: Grade Comparison

\begin{tabular}{|c|c|}
\hline AST60 & AST60X \\
\hline$>$ low $\mathrm{Cr}$ Mo alloyed shell material & $>$ high $\mathrm{Cr}$ Mo alloyed shell material \\
\hline$>$ fine pearlitic microstructure & $>$ tempered bainitic microstructure \\
\hline > Hardness 40-52 Shore C & $>$ Hardness 55-65 Shore C \\
\hline $\begin{array}{l}\text { Up to this hardness best mechanical } \\
\text { properties with good yield and tensile } \\
\text { strength, high elongation and highest } \\
\text { fracture toughness }\end{array}$ & $\begin{array}{l}>\text { higher yield and tensile strength } \\
>\text { better wear resistance } \\
>\text { more homogenous hardness }\end{array}$ \\
\hline $\begin{array}{l}\text { More continuous and later beginning of } \\
\text { crack propagation }\end{array}$ & $>$ Lower speed of crack propagation \\
\hline$>$ Less sensitive roll maintenance & $>$ More sensitive roll maintenance \\
\hline $\begin{array}{l}\text { Quality grade for standard application } \\
\text { in HPM stands in combination with } \\
\text { ICDP or } \mathrm{HCr} \text { work rolls }\end{array}$ & $\begin{array}{l}\text { Quality grade for high loaded } \\
\text { applications in HPM stands, } \\
\text { especially together with HSS rolls }\end{array}$ \\
\hline
\end{tabular}

\subsubsection{Roll Performance}

The performance data of backup roll grade AST60 in single stand (blue color) and double stand mills are illustrated in the following graphs. The roughing stands are indicated with green, the finishing stands with red color (Figure 21 and 22):

* Technical contribution to the 51st Rolling Seminar - Processes, Rolled and Coated Products, October $28^{\text {th }}$ to $31^{\text {st }}, 2014$, Foz do Iguaçu, PR, Brazil. 

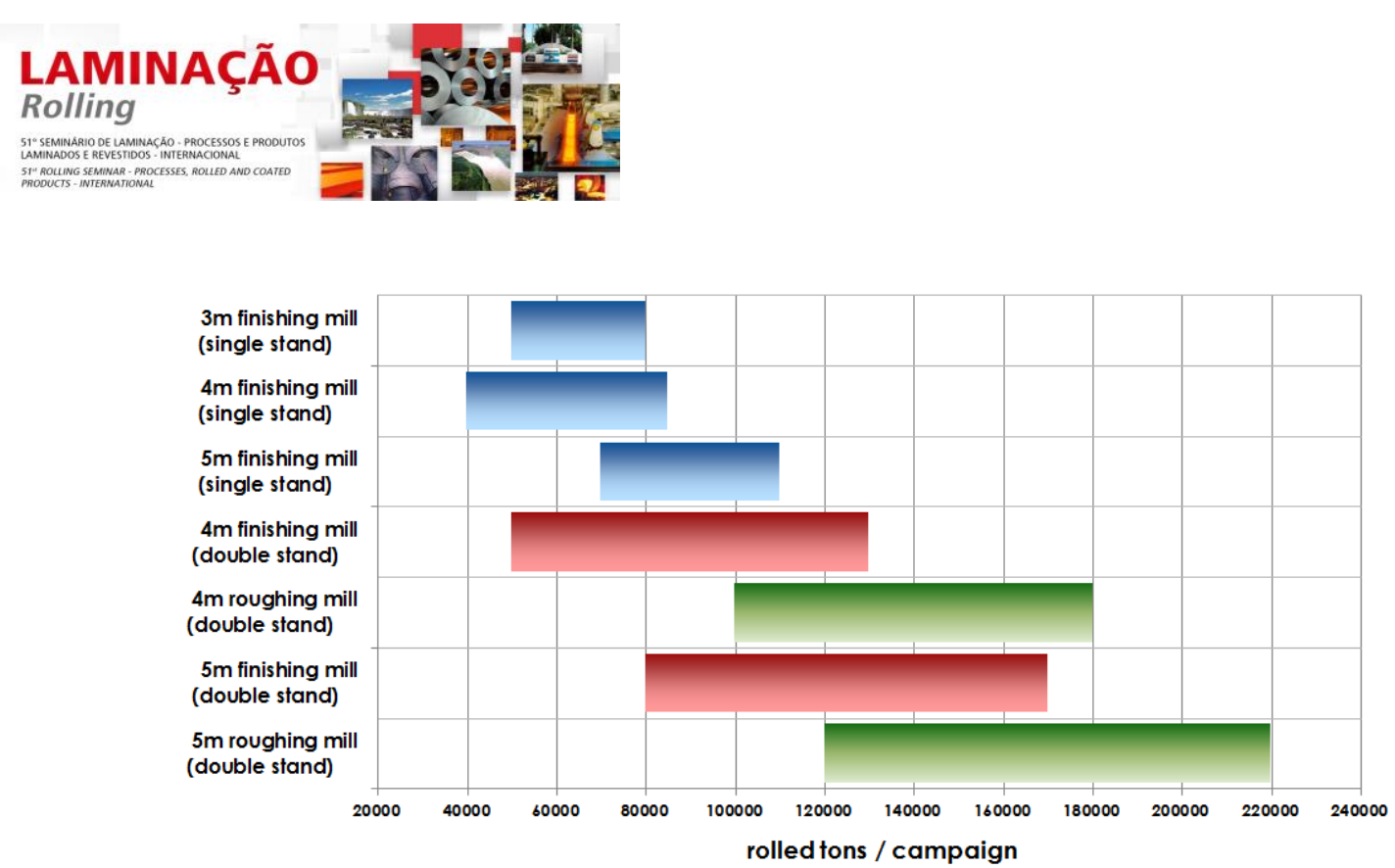

Figure 21: Rolled tons/campaign at different HPM types and barrel length

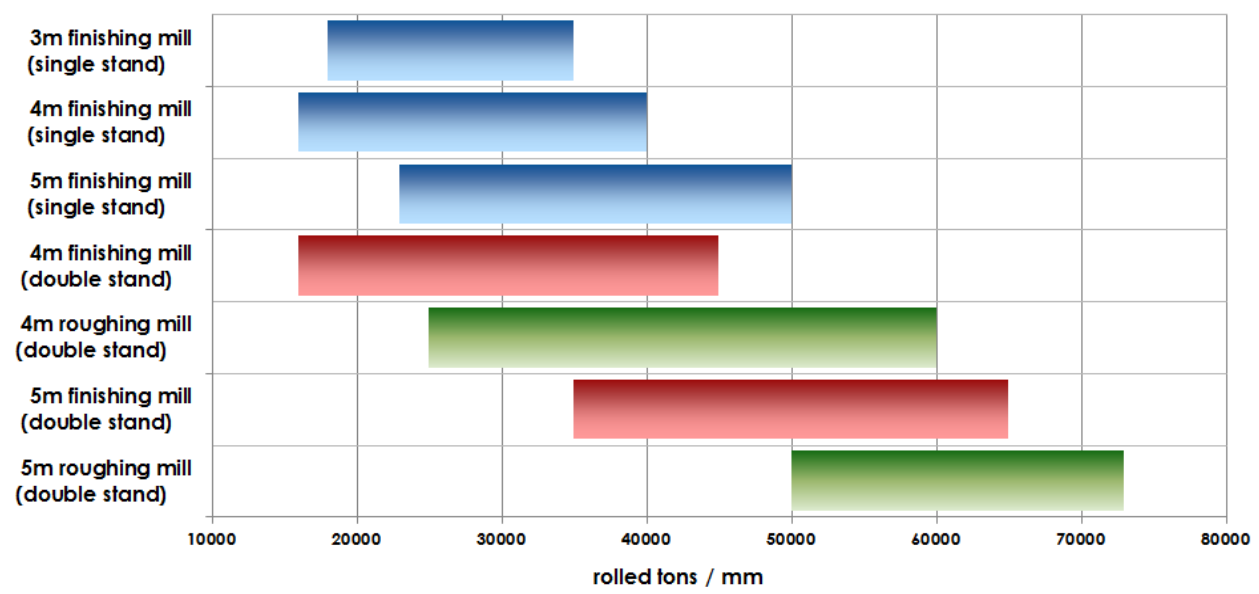

Figure 22: Rolled tons/mm at different HPM types and barrel length

\section{CONCLUSIONS}

The following points summarize the results of this study:

$>$ GP has longtime experience in producing HPM work and backup rolls

> ASIII (ICDP) and ASII80XX (high chromium iron) are standard for GP

$>$ In the future these work rolls will be replaced more and more by HSS work rolls

$>$ In the last 3 years GP further developed the grade AST60 and invented the grade AST60X

$>$ AST60 continues to be the favored grade for standard applications

> AST60X was developed for high loaded applications together with HSS rolls

$>$ GP is prepared for the demands on work and backup rolls in the future.

\section{REFERENCES}

1 VAI-Presentation. Reversing Hot Mills, September 2009, Liege.

2 Heisterkamp P. Enhancements of roll materials for Plate Mill Work Rolls. RAFTS-2012 Conference, Oct. 4-6, 2012, Ranchi, India

3 Cestonaro A, Jacke H, Heisterkamp P. Developments of new materials for plate mill backup rolls...., Presentation to VDEh, September 2013, Hilchenbach

4 Habitzki K. Reduction of Wear on Backup Rolls in Skinpass Mills. AISTech 2014 Proceedings.

* Technical contribution to the 51st Rolling Seminar - Processes, Rolled and Coated Products, October $28^{\text {th }}$ to $31^{\text {st }}, 2014$, Foz do Iguaçu, PR, Brazil. 